\title{
Model Rekording dan Pengolahan Data untuk Program Seleksi Sapi Bali
}

\author{
Hakim, L., Suyadi, V.M.A. Nurgiartiningsih, Nuryadi dan T. Susilawati \\ Fakultas Petrenakan Universitas Brawijaya, Malang
}

\begin{abstract}
INTISARI
Sapi Bali merupakan ternak lokal asli Indonesia sangat berpotensi untuk dikembangbiakkan dan sebagai plasma nutfah harus tetap dilestarikan agar tidak tercemar dengan "darah" bangsa sapi lain. Disinyalir performans sapi Bali cenderung menurun disebabkan aplikasi program pemuliaan yang kurang ketat, sehingga mutu genetiknya rendah. Dalam upaya memperbaiki mutu genetik, Pola Peternakan Inti Terbuka (Open Nucleus Breeding) tampaknya sesuai untuk diterapkan dalam pengembangan sapi Bali yang banyak melibatkan peternakan rakyat sebagai populasi dasar dengan dukungan kegiatan seleksi pada berbagai lapisan peternakan dan harus ditunjang dengan rekording performans produksi dan reproduksi secara tertib, benar dan akurat, serta berkesinambungan. Rekording merupakan metode untuk menunjang keberhasilan program perbaikan mutu genetik ternak yang sangat bermanfaat dalam program seleksi berdasarkan performans individu, dan dapat membantu manajemen beternak yang baik. Dari rekording dapat diketahui silsilah ternak sehingga sangat bermanfaat untuk melakukan analisis komponen ragam dan menduga nilai pemuliaan (breeding value) ternak. Tujuan penelitian untuk mengembangkan manajemen rekording bagi pola perbibitan sapi Bali dan perangkat lunak (software) sistem rekording dan pengolahan data. Luaran berupa laporan Kegiatan Model Rekording dan Pengolahan Data Untuk Program Seleksi Sapi Bali; model rekording sederhana untuk data primer di lapang dan model tabulasi data secara manual; dan perangkat lunak program rekording (sistem rekording data produksi dan reproduksi, rekapitulasi data, faktor koreksi, dan nilai pemuliaan ternak). Kesimpulan adalah perbaikan mutu genetic untuk memperbaiki performans produksi pada keturunan secara bertahap dan kontinyu perlu dilakukan sehingga perlu perencanaan dan implementasi program breeding yang tepat dan berkelanjutan. Diperlukan format recording dan pengolahan data yang sederhana dan standar sehingga mudah diaplikasikan. Program recording di lapangan yaitu recording langsung di lapangan dengan menggunakan lembar isian recording oleh peternak dan komputerisasi data pada petugas atau di pusat pembimbitan, dinas atau instansi terkait. Diperlukan pelatihan mengenai manfaat dan teknik pengisian paket recording baik di tingkat peternak maupun petugas/dinas. Penggunaan perangkat lunak (software) dalam program recording akan sangat membantu dalam pengarsipan, pengolahan dan pencarian data yang diperlukan dalam rangka mendukung program breeding.
\end{abstract}

Kata Kunci : sapi Bali, data, model rekording, program seleksi

\section{PENDAHULUAN}

Ditinjau dari aspek produksi, sapi Bali merupakan ternak potong yang disenangi konsumen karena kadar lemak dagingnya rendah (lean meat), dan karkas yang dihasilkan berkualitas sangat bagus. Keunggulan lain yang dimiliki adalah tingkat kesuburannya yang tinggi, serta daya tahan yang kuat dan dapat berkembang-biak secara cepat pada berbagai kondisi lingkungan tropis di Indonesia (Saka, 2000; Mastika, 2002). Oleh karenanya, dengan berbagai keunggulan tersebut menjadikan sapi Bali sebagai modal dasar genetik sapi lokal di Indonesia. Sebagai ternak lokal asli Indonesia yang mempunyai potensi untuk dikembang-biakkan, keberadaan sapi Bali 
sebagai plasma nutfah harus tetap dilestarikan agar tidak tercemar dengan "darah" bangsa sapi lain. Dari beberapa data yang ada di lapang, menunjukkan bahwa performans sapi Bali pada saat ini cenderung menurun, yang disebabkan oleh program pemuliaan yang tepat kurang dilakukan secara ketat, sehingga mutu genetiknya rendah. Disinyalir juga terjadi pengurasan ternak yang baik performansnya untuk dipotong. Selama tahun 1980 - 1990, rataan bobot badan sapi Bali yang dikeluarkan dari pulau Lombok mengalami penurunan dari $350 \mathrm{~kg}$ menjadi $300 \mathrm{~kg}$ (Dwipa dan Sarwono, 1992; Sarwono, 1995). Bahkan berdasarkan data seri (time series), performans produksi sapi Bali (bobot sapih dan bobot badan umur 1 tahun) yang ada di Pusat Perbibitan Pulukan (P3Bali) selama 9 tahun terakhir ini, juga menunjukkan kecenderungan yang semakin menurun (Hakim, dkk., 2004).

Dalam upaya memperbaiki mutu genetik, Pola Peternakan Inti Terbuka (Open Nucleus Breeding) tampaknya sesuai untuk diterapkan dalam pengembangan sapi Bali yang banyak melibatkan peternakan rakyat sebagai populasi dasar. Namun perlu diperhatikan bahwa dalam kegiatan seleksi pada berbagai lapisan peternakan, harus ditunjang dengan rekording performans produksi dan reproduksi secara tertib, benar dan akurat, serta berkesinambungan. Rekording sebagai tulang punggung keberhasilan program perbaikan mutu genetik ternak, sangat bermanfaat dalam program seleksi berdasarkan performans individu, dan dapat membantu manajemen beternak yang baik. Dengan adanya rekording juga dapat diketahui silsilah ternak, yang sangat bermanfaat untuk melakukan analisis komponen ragam dan menduga nilai pemuliaan (breeding value) ternak (Henderson, 1984; Searle, Casella, dan McCulloch, 1992). Seleksi ternak yang didasarkan pada rekording yang tidak benar, akan mengakibatkan tidak adanya peningkatan performans produksi pada generasi berikutnya, karena terjadi kesalahan dalam memilih ternak yang hanya didasarkan atas besar tubuhnya, terutama bagi ternak jantan sebagai pemacek. Tanpa adanya rekording yang jelas, juga dapat mengakibatkan terjadinya silang-dalam, sehingga dapat memunculnya cacat genetik (Hardjosubroto, 1994).

Dengan adanya data performans produksi dan reproduksi, serta silsilah ternak, maka dapat dilakukan pengolahan data untuk mengetahui lebih lanjut hasil program seleksi yang telah dilaksanakan. Beberapa model rekording yang dapat diterapkan bagi performans produksi sapi Bali, meliputi sifat-sifat kualitatif dan kuantitatif, serta identifikasi individuindividu ternak untuk mengetahui silsilahnya. Sedangkan perangkat lunak (soft-ware) untuk menganalisis data performans produksi individu ternak yang telah banyak dikembangkan, dapat digunakan untuk menduga beberapa parameter genetik dan nilai pemuliaan ternak berdasarkan sifat tertentu.

Kegiatan ini bertujuan untuk: (1) Mengembangkan manajemen rekording bagi pola perbibitan sapi Bali, mencakup format, pelaksanaan, dokumentasi dan rekapitulasi data rekording; (2) Mengembangkan perangkat lunak (software) untuk sistem rekording dan pengolahan data.

\section{MATERI DAN METODE}

Materi dalam kegiatan ini adalah sapi Bali pada berbagai kelompok umur, baik yang ada di Pusat Perbibitan Pulukan, maupun yang ada di Instalasi Populasi Dasar Kabupaten Tabanan, di populasi peternakan rakyat Kabupaten Karang Asem, dan di Balai Inseminasi Buatan Baturiti. Selain itu juga melibatkan para peternak dan petugas teknis lapang dari wilayah kegiatan tersebut.

Data sekunder berupa Laporan Tahunan P3Bali, Laporan Tahunan Dinas Peternakan (Propinsi Bali, Kabupaten Tabanan, dan Karang Asem), dan dokumendokumen yang terkait dengan program breeding di P3Bali, serta data sekunder dan dokumen yang terkait dengan kegiatan P3Bali yang ada di Direktorat Perbibitan 
Direktorat Jenderal Bina Produksi Peternakan, juga merupakan materi dalam kegiatan ini.

\section{Lokasi}

Lokasi dari kegiatan ini adalah propinsi Bali, yang meliputi: (1) Kantor P3Bali di Denpasar, sebagai sentra perencana dan pengendali bagi 2 unit kerja dibawahnya, yaitu Instalasi Populasi Dasar (IPD) dan Pusat Perbibitan di Pulukan; (2) Pusat Perbibitan Pulukan, sebagai stasiun pengujian sapi Bali melalui performance test dan progeny test; (3) Instalasi Populasi Dasar (IPD), sebagai unit kerja teknis dimana terdapat populasi ternak sebagai "dasar program seleksi", dengan misi pembinaan teknis terutama dalam rekording produktivitas ternak. IPD ini berlokasi di Kabupaten Tabanan (Kecamatan Baturiti); (4) Kabupaten Karang Asem, sebagai lokasi pembanding untuk populasi dasar sapi Bali; dan (5) Dinas Peternakan Propinsi Bali; Dinas Peternakan Kabupaten Tabanan; dan Dinas Peternakan Kabupaten Karang Asem.

\section{Waktu}

Kegiatan yang meliputi pra-survei, pengumpulam data primer dan sekunder, analisis data dan interpretasi, serta pelatihan model rekording secara manual bagi peternak dan pelatihan tentang perangkat lunak model rekording bagi petugas teknis Dinas Peternakan, dilakukan pada bulan Juli sampai dengan bulan Nopember 2005.

\section{Metode}

Metode yang digunakan dalam kegiatan ini adalah survei di lapang, dengan lokasi dan materi penelitian diambil secara purposive sampling. Data sekunder dikumpulkan dari berbagai instansi yang terkait dengan P3Bali, untuk dianalisis, dievaluasi, dan diinterpretasikan. Data primer diperoleh dengan cara pengukuran dan pengamatan langsung pada obyek penelitian; sedangkan sebagian data lainnya diperoleh dengan cara wawancara mendalam (deep interview).

\section{Beberapa Kegiatan yang Dilakukan}

1. Mengidentifikasi performans sapi Bali (fenotip), yang meliputi sifat kualitatif dan sifat kuantitatif yakni pola warna tubuh dan keberadaan tanduknya. Statistik vital (tinggi gumba, panjang badan, lingkar dada) dan bobot badan pada berbagai kelompok umur, diukur secara langsung dengan alat ukur meteran dan timbangan; sedangkan performans reproduksi sapi Bali diketahui melalui wawancara mendalam dengan para peternak pemilik sapi sebagai responden. Selain itu, performans sapi Bali juga diketahui dari data sekunder (pengukuran sebelumnya) yang terdapat dalam Laporan Tahunan P3Bali.

2. Menginventarisir dan menganalisis pengetahuan dan kemampuan peternak, petugas teknis lapang Dinas Peternakan Propinsi, Kabupaten, dan di P3Bali, dalam hal manajemen rekording dan tingkat kedisiplinannya.

3. Mendesain format atau model untuk rekording data primer pada kondisi lapang, dan model tabulasi data secara manual. Selain itu dilakukan desain perangkat lunak paket program rekording data (soft-ware), rekapitulasi, dan analisisnya. Dalam hal ini juga dirumuskan faktor koreksi sifat produksi (data lapang yang kondisinya bervariasi) agar lebih adil menganalisisnya.

4. Melakukan uji coba program melalui data simulasi dan beberapa data yang telah diperoleh dari pengamatan di lapang selama kegiatan. Selain itu juga dilakukan penerapan paket program (soft-ware) untuk pendugaan nilai pemuliaan ternak.

5. Melakukan kegiatan pelatihan model rekording data secara manual bagi para peternak; dan pelatihan tentang perangkat lunak paket program rekording data (soft-ware), rekapitulasi, 
dan analisisnya bagi petugas teknis Dinas Peternakan Propinsi Bali, Kabupaten Tabanan dan Karangasem, serta P3Bali. Selama pelatihan juga digali berbagai permasalahan yang terjadi dan dilakukan evaluasi terhadap keberhasilan kegiatan pelatihan.

\section{HASIL DAN PEMBAHASAN}

\section{Tingkat Pendidikan dan Pengalaman Peternak}

Tingkat pendidikan peternak di Kabupaten Tabanan dan Karangasem pada umumnya cukup baik, sebagaimana disajikan pada Tabel 1. Dari komposisi tingkat pendidikannya, ternyata para peternak umumnya telah lulus SMP dan SMA. Hal ini merupakan pertanda yang baik dan positif, karena diharapkan peserta dapat menerima materi pelatihan secara baik. Hal ini dapat dirasakan saat berlangsungnya pelatihan pada sesi tanya jawab, terjadi diskusi dan interaksi yang cukup kondusif. Berdasarkan hasil pengisisn kuisioner, sebanyak 98 persen peserta menjawab sangat mengerti isi materi yang diberikan. Dari tingkat pendidikan dan pengalaman beternak yang cukup baik, diharapkan program rekording dan seleksi sapi Bali di daerahnya masing-masing dapat dilakukan dengan baik dan berkesinambungan.

Tabel 1. Tingkat Pendidikan Peternak Peserta Pelatihan Rekording di Kabupaten Tabanan dan Karangasem

\begin{tabular}{llll}
\hline \hline No. & Pendidikan & Tabanan $(\%)$ & Karangasem $(\%)$ \\
\hline 1. & SD & $20(09 / 45)$ & $39(14 / 36)$ \\
2. & SMP & $38(17 / 45)$ & $17(06 / 36)$ \\
3. & SMA & $42(19 / 45)$ & $44(16 / 36)$ \\
\hline
\end{tabular}

Peternak peserta pelatihan mempunyai persepsi dan tanggapan yang sangat positif terhadap program rekording. Sebagian besar $(96 \%)$ peserta menyatakan perlunya rekording dilakukan untuk perbaikan mutu genetik sapi Bali. Kesadaran ini terbukti dengan keinginan peternak yang memandang perlunya diadakan pelatihan tentang rekording.

\section{Populasi Sapi Bali di Kabupaten Tabanan dan Karang Asem}

Keberadaan sapi Bali di Propinsi Bali menyebar di seluruh Kabupaten, yang berdasarkan data Cacah Jiwa Ternak Tahun 2003, populasinya sebesar 539.781 ekor, terdiri dari Pejantan 80.630 ekor, Jantan Muda 81.808 ekor, Anak Jantan 65.746 ekor, Jantan Dikebiri 1.349, Induk 175.293, Betina Muda 70.084 ekor, Anak Betina 64.871 ekor. Dibandingkan dengan keadaan tahun 2002 yang populasinya sebesar
521.973 ekor, ada kenaikan populasi sebanyak 3,41\%. Pada masa yang akan datang, diharapkan terjadi peningkatan populasi, sejalan dengan pertambahan penduduk dan meningkatnya konsumsi pangan protein hewani asal ternak, khususnya sapi potong.

\section{Karakteristik Fenotip dan Ukuran Statistik Vital Sapi Bali}

Dari pengamatan contoh ternak dalam penelitian ini, diperoleh gambaran tentang karakteristik fenotipe sapi Bali, sebagai berikut: (1) Bergelambir kecil; (2) Warna muka sama dengan warna tubuh; (3) Warna kulit dominan adalah merah coklat dan merah bata; (4) Batas warna tubuh dengan warna pantat adalah jelas, tetapi sebagian besar juga smear; (5) Batas warna tubuh dengan warna kaki dari lutut kebawah adalah jelas; (6) Bulu ekor berwarna hitam; (7) Terdapat garis hitam pada telinga; (8) 
Punggung lurus; (9) Terdapat garis belut atau garis hitam di bagian punggung; (10) Terdapat tanduk; (11) Arah tanduk mengarah ke belakang; dan (12) Tidak berpunuk. Karakter yang dapat diidentifikasi dalam penelitian ini, sesuai dengan yang pernah dikemukakan Pane (1991). Walaupun demikian, ditemukan beberapa sapi Bali (dalam skala kecil) di ketiga lokasi penelitian yang menyimpang dari karakteristiknya, misalnya: (1) Terdapatnya gelambir yang lebar dan tebal; (2) Batas warna di bagian pantat dan kaki smear; (3) Bulu ekor berwarna putih; (4) Tidak terdapat lingkar hitam pada mata dan garis hitam pada telinga; (5) Punggung tidak lurus; (6) Tidak bertanduk atau arah tanduk ke depan dan keatas; dan (7) Berpunuk besar atau kecil. Terjadinya penyimpangan karakteristik ini dapat diduga karena beberapa kemungkinan, diantaranya terjadinya mutasi, dan masuknya gen baru dari bangsa sapi lain akibat persilangan.

Di Kabupaten Tabanan, sejumlah contoh (48 ekor) sapi Bali yang diamati ukuran statistik vitalnya, terdistribusi dalam berbagai kelompok umur yang didasarkan atas pertumbuhan giginya. Ukuran statistik vital sapi Bali di Kabupaten Tabanan pada umur PI-0 sampai PI-4 masih menunjukkan peningkatan; tetapi setelah PI - 4 sampai PI 8 relatif tetap. Ukuran statistik vital dan bobot badan sapi Bali di Kabupaten Karang Asem juga mempunyai pola yang sama dengan pola di Kabupaten Tabanan.

\section{Performans Produksi dan Reproduksi Sapi Bali}

Produktivitas ternak dapat dinilai dengan menggunakan ukuran bobot sapih dan bobot badan umur 1 tahun. Berdasarkan data seri (time-series) selama 9 tahun terakhir di Pusat Perbibitan Sapi Bali, menunjukkan bahwa bobot sapih dan bobot badan umur 1 tahun ada kecenderungan semakin menurun. Apabila pola pemeliharaan dilakukan sejak ternak dilahirkan, maka terjadinya penurunan bobot sapih kemungkinan disebabkan oleh rendahnya bobot lahir maupun kurangnya produksi susu induk saat menyusui sebagai akibat kurangnya pakan yang diberikan, sehingga tidak mencukupi kebutuhan anaknya. Rendahnya bobot badan umur 1 tahun berdasarkan data seri tersebut, mengindikasikan bahwa manajemen yang diterapkan masih kurang standar, termasuk kurang dan rendahnya kualitas pakan. Berdasarkan pengamatan di lapang, kondisi padang penggembalaan (ranch) di Pusat Perbibitan memang menunjukkan kurangnya rumput yang tumbuh.

Service per conception sapi Bali di Kabupaten Tabanan adalah 1,02, dan di Kabupaten Karang Asem 1,16; sedangkan di Pusat Perbibitan tidak tersedia data. Days open sapi Bali di Kabupaten Tabanan adalah 117,39 hari, dan di Kabupaten Karang Asem 106 hari; sedangkan di Pusat Perbibitan juga tidak tersedia data. Berdasarkan data tersebut menunjukkan bahwa tampilan reproduksi selama 10 tahun di Populasi Dasar Kabupaten Tabanan adalah yang terbaik.

\section{Format Rekording dan Tabulasi Data Secara Manual di Lapang}

Format rekording yang dimaksud meliputi lokasi peternak, identitas peternak, identitas sapi, sifat kualitatif dan sifat kuantitatif sapi yang diamati. Isian lokasi peternak diawali dengan tanggal rekording, yaitu tanggal dimana peternak melakukan pengamatan dan pengukuran terhadap sapi yang dimilikinya. Tanggal rekording sangat penting dalam suatu pencatatan ternak karena dapat digunakan sebagai pedoman untuk mengetahui tingkat pertumbuhan ternak. Selain tanggal rekording, lokasi peternak juga didiskripsikan secara detail, dimulai dari propinsi hingga kelompok peternak dan nama pembinanya. Data seperti ini diperlukan untuk menghindari kesamaan identitas, baik dari sisi peternaknya maupun sapi yang dimilikinya.

Sifat-sifat kualitatif dan kuantitatif setiap individu sapi diperlukan untuk mengetahui keaslian sapi Bali berdasarkan 
penampakan sapi tersebut. Sifat-sifat kualitatif yang diamati meliputi warna kulit, kejelasan batas warna, ada tidaknya garis belut, ada tidaknya tanduk, arah tanduk, ada tidaknya punuk, dan ada tidaknya gelambir. Sedangkan sifat-sifat kuantitatif meliputi bobot lahir, umur sapih, bobot sapih, umur beranak pertama, tinggi gumba, panjang badan, lingkar dada, bobot badan umur tertentu, jumlah kawin hingga bunting, lama kosong dan selang beranak. Sifat-sifat kualitatif dan kuantittif yang disebutkan tersebut diharapkan sudah dapat menggambarkan performans sapi Bali yang ada saat ini.

\section{Desain Perangkat Lunak (Software) Program Rekording Sapi Bali}

Dalam mendesain perangkat lunak (software) program rekording dan pengolahan data sapi Bali, dilakukan melalui beberapa tahapan diantaranya: (a) Melakukan diskusi dengan Tim; (b) Transfer konsep; (c) Mendesain prototipe dan desain awal sistem rekording; (d) 2 . Tahap Kedua, yaitu: (e) Melakukan analisa sistem dan desain sistem secara menyeluruh; (f) Membuat prototipe sistem dan struktur data dasar sistem di semua aspek yang akan diprogramkan; (g) Melakukan uji kelayakan sistem; (h) Melakukan evaluasi sistem; (i) Melakukan uji keterkaitan sistem atau program rekording sapi Bali dengan program atau software terkait atau software payung, yang dalam hal ini adalah windows; 5.

\section{Rumusan Faktor Koreksi Data Primer di Lapang}

Bobot sapih merupakan salah satu sifat yang sering digunakan sebagai kriteria seleksi pada sapi potong karena bobot sapih mempunyai nilai heritabilitas yang cukup tinggi dan keragaman antar individu juga tergolong tinggi. Untuk memperoleh hasil analisis genetik yang akurat maka kriteria seleksi harus dikoreksi terhadap faktorfaktor yang mempengaruhi besarnya nilai kriteria tersebut. Hasil pengamatan di lapang menunjukkan bahwa umur pada saat penyapihan sangat bervariasi antar individu ternak, yaitu berkisar antara 111 sampai dengan 308 hari. Berdasarkan kenyataan tersebut maka sebagai kriteria seleksi, bobot sapih harus dikoreksi terhadap umur penyapihan. Menurut Hardjosubroto (1994) pada sapi Bali umumnya dilakukan standarisasi bobot sapih pada umur 205 hari, yang berarti bahwa pedet diasumsikan ditimbang pada umur yang seragam yaitu 205 hari. Bobot sapih terkoreksi pada umur 205 hari dihitung dengan rumus sebagai berikut:

$$
B S_{205}=\left(\frac{B B-B L}{U m u r} \times 205+B L\right)(F K U I)
$$

(Hardjosubroto, 1994)

\section{Analisis Data Performans Produksi Untuk Program Seleksi}

Data performan produksi yang digunakan dalam analisis untuk software rekording ini adalah bobot lahir, bobot sapih, bobot badan saat pengukuran, statistik vital yang meliputi tinggi gumba, panjang badan dan lingkar dada. Menurut Hardjosubroto (1994), pada sapi potong karakter produksi seperti bobot badan dan pertambahan bobot badan harian mempunyai nilai heritabilitas yang tinggi. Sebagai contoh nilai heritabilitas bobot lahir adalah 0,20 sampai 0,58 ; berat sapih 0,3 sampai 0,55 ; pertambahan bobot badan harian adalah 0,45 sampai 0,50. Besarnya nilai heritabilitas tersebut memungkinkan para pemulia (breeder) untuk menyeleksi sapi potongnya berdasarkan karakter tersebut.

\section{Analisis Data Performans Reproduksi Untuk Program Seleksi}

Service per conception atau jumlah perkawinan hingga tejadinya suatu kebuntingan sapi Bali di Kabupaten Tabanan adalah 1,02, dan di Kabupaten Karangasem 1,16. Hal ini menunjukkan data 
yang baik sebab sebagai pedoman $\mathrm{S} / \mathrm{C}$ yang baik adalah kurang dari 1,5. Data calving interval di kabupaten Karangasem adalah 12,53 bulan sedangkan di kabupeten Tabanan adalah 13,26 bulan hasil tersebut menunjukkan efesiensi Reproduksi yang baik sekali, hal ini mengingat bahwa lamanya bunting adalah 9 bulan dan sepuluh hari maka Days open sapi Bali di Kabupaten Tabanan adalah 117,39 hari, dan di Kabupaten Karangasem 106 hari; Semakin pendek interval beranak, maka semakin optimum jumlah anak yang dilahirkan selama hidupnya. Data yang dipergunakan untuk mengukur efisiensi reproduksi adalah nilai $\mathrm{S} / \mathrm{C}$, Conception Rate (CR) dan Angka Kebuntingan.

\section{Menduga Nilai Pemuliaan dan Parameter Genetik Dalam Program Seleksi}

Berdasarkan data primer yang terkumpul di lapang tampak bahwa infromasi silsilah dari masing-masing individu ternak kurang lengkap. Informasi tentang pejantan (sire) dan induk (dam) dari masing-masing individu sapi hanya terbatas pada masing-masing lokasi dimana ternak tersebut berada; yang berarti bahwa kode yang sama kemungkinan besar dimiliki oleh beberapa pejantan. Hal ini menyebabkan hubungan antar saudara dari individuindividu dalam populasi ternak tidak dapat diketahui. Hubungan antar saudara ini merupakan dasar untuk dapat mengestimasi komponen ragam genetik dari ternak dalam populasi.

Berdasarkan hasil rekording di lapang serta pertimbangan nilai heritabilitas yang cukup tinggi, dengan asumsi nilai heritabilitas bobot sapih sebesar 0,4, maka sifat yang digunakan sebagai kriteria seleksi dalam software rekording sapi Bali dalam hal ini adalah bobot sapih. Nilai Pemuliaan untuk bobot sapih menggambarkan nilai mutu genetik individu untuk bobot sapih yang diberikan secara relatif berdasarkan kedudukannya dalam populasi. Nilai pemuliaan seekor ternak diestimasi dengan rumus sederhana sebagai berikut: $\hat{a}_{i}=b\left(y_{i}-\mu\right)$, dimana $\mathrm{b}=$ regresi nilai pemuliaan sesungguhnya pada performan fenotip yang dinilai; $\mu=$ rataan performan ternak pada suatu populasi dimana ternak $\mathrm{i}$ berasal. Karena b sama dengan rasio peragam genetik ternak dan fenotipnya dengan ragam fenotip, maka $b$ identik dengan nilai heritabiliats $\left(h^{2}\right)$. Berdasarkan rumus tersebut maka nilai pemuliaan bobot sapih dari masing-masing individu dapat dihitung dengan rumus sebagai berikut (Hardjosubroto, 1994; dan Mrode, 2000): $N P=h^{2}\left(y_{i}-\mu\right)$.

\section{KESIMPULAN}

Berdasarkan temuan studi awal diperoleh gambaran bahwa sapi Bali mengalami penurunan performans produksi dari tahun-tahun ke tahun secara konstan. Perbaikan mutu genetic untuk memperbaiki performans produksi pada keturunan secara bertahap dan kontinyu perlu dilakukan. Hal ini dapat ditempuh melalui perencanaan dan implementasi program breeding yang tepat dan berkelanjutan, Agar program breeding dapat berjalan sesuai dengan garis-garis perencanaan maka diperlukan format rekording dan pengolahan data yang sederhana dan standar sehingga mudah diaplikasikan. Program rekording di lapangan dapat dibagi menjadi dua komponen yaitu recording langsung di lapangan dengan menggunakan lembar isian rekording oleh peternak dan komputerisasi data pada petugas atau di pusat pembimbitan, dinas atau instansi terkait, agar program rekording dapat berjalan dengan benar maka diperlukan pelatihan mengenai manfaat dan teknik pengisian paket rekording baik di tingkat peternak maupun petugas/dinas.

Penggunaan perangkat lunak (software) dalam program recording akan sangat membantu dalam pengarsipan, pengolahan dan pencarian data yang diperlukan dalam rangka mendukung program breeding. 


\section{DAFTAR PUSTAKA}

Dwipa, I.B.G. dan B.D. Sarwono, 1992. Musim dan Bobot Badan Sapi Bali yang Di-antar-pulaukan dari Lombok. Jurnal Penelitian Universitas Mataram, Nusa Tenggara Barat. I(2): 1 - 10.

Hardjosubroto, W. 1994. Aplikasi Pemuliabiakan Ternak di Lapangan. PT Gramedia Widiasarana Indonesia, Jakarta.

Henderson, C.R. (1984) Estimation of variance and covariance under multiple traits models. Journal Dairy Sci. 67:1581-1589.

Mastika, I.M. 2002. Feeding Strategies to Improve the Production Performance and Meat Quality of Bali Cattle (Bos sondaicus). Working Papers: Bali Cattle Work-shop. Bali, 4 - 7 February 2002.

Mrode, R. A. (2000) Linear Models for the Prediction of Animal breeding Values. CAB International, UK.
Saka, I.K. 2000. Potensi Sapi Bali Sebagai Ternak Potong Ditinjau Dari Karakteristik Karkas. Prosiding Seminar Nasional Peranan Balai Inseminasi Buatan Singosari Dalam Menghadapi Swasembada Daging Tahun 2005 Melalui Uji Keturunan Sapi Bali dan KSO Semen Beku. Universitas Brawijaya, Malang.

Sarwono, B.D. 1995. Penggemukan Sapi Rakyat: Kemitraan Pedagang Ternak Dengan Petani di Lombok, Nusa Tenggara Barat. Prosiding Simposium Nasional Kemitraan Usaha Ternak: "Industrialisasi Usaha Ternak Rakyat Dalam Menghadapi Tantangan Globalisasi”. Ikatan Sarjana Ilmu-Ilmu Peternakan Indonesia Bekerja-sama Dengan Balai Penelitian Ternak Ciawi, Bogor, 30 - 31 Agustus 1995.

Searle, S.R., G.Casella, dan C.E. McCulloch. 1992. Variance Components. Willey and Sons. New York. 